УДК 821.161.2 (Марія Матіос):155.9:159.964.2

Підгорна Оксана, аспірантка кафедри української та світової літератур Криворізький державний педагогічний університет

\title{
АРХЕТИПНА СТРУКТУРА БУКОВИНСЬКОГО НАРАТИВУ МАРІЇ МАТІОС (контекст роману “Солодка Даруся»)
}

У запропонованій статті проаналізовано один зі способів прикладної психоаналітичної інтерпретації художніх текстів - юнгіанський, спрямований на виявлення у творі ефектів несвідомого, свідомого (зрілого) «Я» та колективного несвідомого у формі архетипів. Застосовуючи аналітичну психологію К.-Г. Юнга, здійснено спробу архетипного дослідження буковинського наративу Марії Матіос (на матеріалі роману «Солодка Даруся»). Доведено, щзо в основі психотравматичного досвіду Дарини Іламук та ї психологічної залежності від подій минулого лежать неприйняття «Я», пригнічення архетипів «Тінь та «Персона», похибка проиесів індивідуації та самості.

Ключові слова: психоаналітичне літературознавство, аналітична психологія, архетип, Матіос Марія, «Солодка Даруся» \section{Darusia").}

Architect ctructure of bukovinskiy narativ Mariy Matios (context of the novel "Sweet

The proposed article analyzes one of the methods of applied psychoanalytic interpretation of artistic texts - Jungian, aimed at revealing in the work of the effects of the unconscious, conscious (mature) "I" and the collective unconscious in the form of archetypes. Applying the analytical psychology of K.-G. Young, an attempt was made to archetype study of the Bukovinian narrative of Maria Matios (on the material of the novel "Sweet Darusia"). It is proved that the basis of psychotraumatic experience of Daryna Ilashchuk and its psychological dependence on the events of the past are the rejection of the "I", suppression of the archetypes "Shadow and Person," the error of the processes of individuality and self.

Key words: psychoanalytic literary studies, analytical psychology, archetype, Matios Maria, "Sweet Darusia".

Постановка проблеми у загальному вигляді та іï зв'язок із важливими науковими чи практичними завданнями. Творчість Марії Матіос, зокрема прозопис - цікаве i багато в чому унікальне явище у 
новітньому літературному процесі. Досконалий психологізм iї художніх полотен, створення художніх образів і такого хронотопу твору, які адекватно передають каузальність та наслідки поведінки образів-персонажів, спроби художнього моделювання взаємовпливу та взаємозалежності історій індивідуальних (особистих) та колективних (національних), написання «творівбатогів», які, між іншим, таврують психотравматичну «історію, яка не припиняє їхати колесами по людях» характеризують, на нашу думку, особливості художнього письма М. Матіос. Для потрактування базових смислів, що їх заклала автор у канву прозових текстів, буковинського циклу, зокрема, використовується чимало інтерпретаційних стратегій (у тому числі, модерної аналітики). Не зважаючи на те, що у сучасному теоретиколітературному дискурсі психоаналітичне «прочитання» сприймається неоднозначно, а надто - коли йдеться про твори класиків [Бідюк 2009 : 3], психоаналітична методологія дозволяє «продуктивно й иікаво інтерпретувати художні тексти», позаяк <..> «за допомогою психоаналітичних технік прочитання художній твір стає відкритим, презентуючи свої глибинні пласти художності, стаючи схожим на «перевернуту лійку» (Гадамер), звідки ми отримуємо потік глибинних знань про світ» [Вертипорох 2013 : 106]. Зміст та символіка буковинського наративу Марії Матіос не можуть бути адекватно розтлумачені 3 використанням усталеного канону-кліше: нам важливо зрозуміти, чому герой мовчить, тобто мовчанням говорить саме про таку сторону свого буття, «щ⿻о він не хоче сказати, або навіть не припускає того, щ⿻о він хотів сказати» [Цит. за: Вертипорох 2013 : 106]. Понад це, результатом застосування психоаналітичної стратегії до матеріалу прози М. Матіос (зокрема, фройдівської традиції) є знаходження «класичних психоаналітичних симптомів: едіпів комплекс [Підгорна 2017], фантазування, сни, галющуинащї, ерос-танатос (лібідо-мортідо $і$ т.д.), сублімащія, невроз-психоз» [Вертипорох 2013 : 108]. 3 огляду на зазначене вище, пропонуємо дослідити буковинський наратив Марії Матіос у контексті «колективного несвідомого» та його ядерних структур - архетипів. 
Аналіз останніх досліджень і публікацій, в яких започатковано розв'язання даної проблеми і на які спирасться автор. Архетипні образи вперше набули теоретичного обгрунтування у працях швейцарського психолога К.-Г.Юнга («Архетип - цее чиста, незабруднена природа. Саме ияя природа примушує людину промовляти слова та виконувати дї, сенс яких вона не усвідомлює, настільки не усвідомлює, щуо навіть не замислюється над ними [Юнг 2002 : 56]), а згодом були розвинені літературознавцем Н. Фраєм у концепції міфокритики та відомій «Анатомії критики» [Маланій 2014 : 73 ]. Імплементація міфів, міфологічних сюжетів, міфологем i архетипів у літературні тексти прослідковується протягом всієї історії літератури різних країн. До прикладу, деякі сучасні західноєвропейські письменники (П. Кіньяр) свідомо використовують «міф як культурний артефакт <..>, апелюють до міфологічних архетипів, застосовують «археологічний метод, щзо являє собою дослідження «культурного філогенезу», а мова та міф - ие «instrument fouisseur», землерийний інструмент, за допомогою якого письменник переосмислює історію культури» [Мацюк 2015].

Ще на початку XX століття, $\mathrm{X}$ наукових розвідках С. Балея, С. Гаєвського, В. Підмогильного, з’явилися перші спроби застосування психоаналітичної моделі для пояснення формантів авторського «Я», або створення психобіографії митця (наприклад, Шевченка Т. Г., НечуяЛевицького I. С.) на українському грунті. Фактично ж в українській літературі першим художньо застосував психолого-психоаналітичну стратегію яскравий буковинський наратор М. М. Коцюбинський - майстер психологічного імпресіонізму, який разом 3 іншими письменниками-сучасниками «занурювали(в)ся у внутрішній світ людини, намагали(в)ся збагнути його, показати процеси, які в ньому відбуваються» [Кузнецов 2014 : 104]. Наприкінці XX - початку XXI століття психоаналітичний вектор українського літературознавства розроблявся Г. Грабовичем, О. Забужко, Н. Зборовською, М. Ласло-Куцюк, Г. Левченко, М. Моклицею, С. Павличко, Л. Плющем, Я. Печарським, О. Тиховською, О. Бідюк. 
Більшого поширення та розголосу набув фройдизм із базовими ідеями про індивідуальне несвідоме та сексуальні потяги; 3. Фройд, власне, спрямував психоаналіз у русло дослідження літератури [Бідюк 2009 : 4], К.-Г. Юнг описав певні пракомпоненти - архетипний устрій, а також визначив відповідність між образами та архетипами (наприклад, архетип Самості; його можна побачити в образі мандали, міста, храму, Христа, божественно народженої дитини тощо) [Бідюк 2009 : 5]. У сучасному прикладному психоаналітичному юнгіанському дискурсі цікаві розвідки М. Нестелєєва (автодеструкція архетипу Самості) [Нестелєєв 2016], М. Лаврусенко (архетип Матері), В. Густодимової (юнгіанське тлумачення психологічної залежності як особистісної девіації [Густодимова 2013]. Серед відомих автору досліджень прозової спадщини буковинського циклу Марії Матіос відсутні системні юнгіансько-центричні пошуки та архетипна аналітика. У наукових розвідках Н. Косинської, втім, акцентовано кілька архетипів, на матеріалі яких можна вдало інтерпретувати «трагедію, адекватну історії».

Так, наприклад, ескапізм Дарусі у формі «удаваного божевілля та мовчання як втеча від гендерної ролі, нав'язаних суспільством уявлень “про адекватність"» [Косинська 2009 : 35] зручно потрактувати як прояви архетипів Персони, Тіні, Самості. На сьогодні за основний об'єкт літературознавчого психоаналізу вважають текст, апелюючи при цьому до психології митця та авторського «Я», а також «найменші елементи, які, на перший погляд, видаються несуттєвими, ховаються в «тіні» образного та мотивного рівнів художнього твору» [Бідюк $2009: 4]$.

Виділення невирішених раніше частин загальної проблеми, котрим присвячусться означена стаття.

Наша розвідка присвячена дослідженню основних формантів юнгіанської психоаналітичної інтерпретації [Вертипорох 2013 : 110] на матеріалі конкретного тексту «буковинської саги» Марії Матіос - роману «Солодка Даруся». У межах пропонованої статті ставимо собі такі завдання: 
1. Виявити ознаки неусвідомленого, свідомого «Я» та колективного позасвідомого (архетипів) через символічність тексту;

2. Віднайти у тексті художнє відображення архетипів Великої Матері, Вічної Дитини, Старого Мудреця, Діви, Духу, Священного шлюбу;

3. Виявити на текстуальному рівні архетипи Тіні (примітивні потяги), Персони (пристосування до зовнішнього світу), Аніми (неусвідомлена жіноча сутність чоловіка), Анімусу (неусвідомлена чоловіча сутність жінки), Самості (досягнення рівноваги між індивідуальним i колективним несвідомим), Індивідуації (розвиток індивіда, посвячення його у зовнішній світ - Персона - i внутрішній - відокремлення індивідуальної психології від колективної) [Вертипорох 2013 : 110], а також їх вплив на екзистенціал «Дарусі як тексту».

Формулювання цілей статті (постановка завдання). Проаналізувати зміст психоаналітичного дискурсу роману Марії Матіос «Солодка Даруся», застосовуючи одну 3 методик психоаналітичного літературознавства архетипний (юнгіанський) аналіз.

Виклад основного матеріалу дослідження 3 повним обгрунтуванням отриманих наукових результатів. 3. Фройд був першим, хто передбачив наявність у підсвідомому «архаӥчних залишкових форм та примітивних способів функціонування» [Юнг 2002 : 46]. Явище, що воно буде назване у юнгіанській парадигмі архетипом, являє собою «порожній, формальний елемент...є чимось на зразок а priori заданої формальной можливості уявлення» [Юнг 2012 : 112; Цит. за: Нестелєєв 2016 : 155].

Утім, архаїчні залишкові форми є універсальним інструментом переробки індивідуального досвіду, фактично автономного, а формально - спільного для багатьох поколінь та незалежного від фізичного та соціального статусу індивіда, тобто «практично в усіх нормальних типах фантазї наявні ті самі архетипи» [Юнг 2014 : 126; Цит. за: Нестелєєв 2016 : 155]. Кожен із архетипів не існує автономно і не виникає симультанно; вони - архетипи - зазвичай утворюють певні симптомокомплекси, мають при цьому каузальну логіку 
виникнення; «Вони є комплексами переживань, щуо вступають у наме життя $i$ діють на нього, як доля» [Юнг 2014 : 117; Цит.за: Нестелєєв 2016 : 156].

Головна героїня «драми на три життя» Дарина Ілащук, вона ж - солодка Даруся, як особистість - внутрішньо адекватно самоідентифікована, лінія їі поведінки - визначена та внутрішньо легітимізована. Одначе «статус героїні визначається через стосунок до суспільства», "... про неї, яка говорить 3 деревами $i$ квітами, $i$ живе собі, як хоче, хоч $i$ шкоди не робить нікому, думають як про дурну» [Матіос 2005 : 12]. В основі подібного дисонансу «внутрішньо легітимізованої» та «очікуваної іншими» Персони лежить почуття страху - не самоти, а болю - що завжди з'являсться «з допомогою» людей, які вриваються в їі усамітнення. Так звана «конфета», або лише згадка про неї

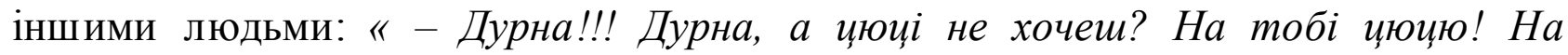
цүюию! - $і$ кинув жменю барбарисок під самі хатні двері.... Був би ліпме не нагадував про иุющю. У селі ніхто розумний не нагадує $і$ не дає Дарусі конфет: знає, щзо від солодкого болить ї̈ голова і блює вона дуже» [Матіос 2005 : 5] $\epsilon$ позірною причиною Дарусиної німоти: «... з людыми вона не хоче говорити («... Не могти заплакати-заридати, викричатися, засміятися, а бути живою мумією і мати в голові велику, як від кулі, рану. <..> Голову зносило кудись так далеко, щзо вона чимдужче тримала ї̈ руками, ніби боронилася від злодія. Якби той злодій був такий добрий, та закликав якогось різника, <..> щзоб вирізав біль з Дарусиної голови, то була б рада i, може, нарешті заговорила» [Матіос 2005 : 6]. Символічний натяк на неприймання героїнею власного темного (читай - винного) альтер-Его можемо побачити у таких текстуальних проекціях: «від солодкого болить ӥи голова $i$ блює вона дуже» [Матіос 2005 : 13] (опір травматичним переживанням, бажання вивести назовні травму «Я - зрадниця»), «вони думають, щзо вона німа. А вона не німа. Даруся просто не хоче говорити" [Матіос 2005 : 17]; Даруся мовчить, бо ж на власному прикладі відчула, що слово завжди вимагає відповідальності, що словом найпростіше завдати лиха та страждання [Цит. за: Підгорна 2017]. 
Надмірне суб’єктивно загострення почуття провини, гріха та незумисного злочину становлять ядро психотравми героїні, а порушена вербалізація внутрішньо схвалений спосіб спокути та пам’яті $є$ змістом архетипу Тінь. У такий спосіб оприявнюється зміст архетипів Аніма-Анімус (їх символічний синтез в образі матері Матронки - архетип Великої Матері): відторгнення нею доньки («Краще би була струїла в утробі таку нечисть чи родила німою»), безумовно, додатково вплинуло на внутрішньо дозволене героїнею німування, бо ж «Формуючи аудиальні перцеепиіï дитини, матір стає структуроутворюючим началом у ї̈ звуковому, а потім і мовленнєвому світі» [Мацюк 2015].

За аналітичною стратегією К.-Г. Юнга, навіть спонтанна поведінка алгоритмізована, і особливу роль у ній відіграють сенсорно-перцептивні опори, асоційовані з досвідом (травматичним) людини. Тому «Аморфних інстинктів фактично не існує, тобто кожний інстинкт несе у собі патерн ситуації, щзо йому відповідає. Він завжди уособлює певний образ, із незмінно наявними $у$ нього рисами [Юнг 2002 : 46]. Позаяк поведінка завжди провокативна, змінюючи інстинкт, треба змінити домінуючий патерн. Адекватна оцінка Тіні, ii раціоналізація та прийняття як фактичного досвіду індивідуальної життєвої історії, або асоційована Тінь були би ознакою одужання героїні і, відповідно, формування готовності прийняти як даності того, що є в мені негативного, сприяло б народженню Самості, бо ж «проблема «усвідомлення тіні», ріст усвідомлення нижньої (підлеглої) частини особистості <..> має набагато більше значення у стражданнях та пристрасних захопленнях, ніж це притаманне усій особистості [Юнг 2002 : 54].

Іноді зміст основної травми героїні витісняється («3 якоїсь страшної миті в дитинстві, котру Даруся ніяк не може пригадати [Матіос 2005 : 6]), i тоді Даруся напевне не може відповісти на питання «Хто я?», тому що кількість полярних аутохарактеристик лімітована, а емоційно контрастний коментар сприймається недовірливо. «Людина без тіні» - цее статистично звичайний 
людський тип: той, хто уявляє, щуо дійсно є тим, щуо він, щуо він має знати про себе» [Юнг 2002 : 54].

Архетип Анімусу з'являється вперше в особі конкретного чоловіка - носія фізичної сили - батька («А Даруся не хоче не тужити за татом. Бо для неї тут не туга - тут, коло тата, лиш стільки ї̈ справжнього життя. <...> Ото вона й не палить свічку: боїться, щзо<> голос більше не зустріне ї̈. Що вона тоді робила б?... Якщчо не буде його голосу - не стане $\boldsymbol{i}$ ї̈» [Матіос 2005 : 31]), пізніше нівелюється в образі офіцера НКВС i ретранслюється сюжетно в особі Івана Цвичка («A вона під його голос гейби оживає: і ходить пряміше, і в кутику губів складочка, як від потайної усмішки, а найголовніме - голова їй перестає боліти» [Матіос 2005 : 57]). Фізична втрата батька, соціальна та фізична - матері («Матронка висіла <..> з чорним, висолопленим з рота язиком») є жахливим опредмеченням спокути за гріх, навіть неусвідомлений або вимушений. Позаяк «Усвідомлення власної тіні на вміння обходитися з нею - обов'язок кожного» [Юнг 2003 : 321], героїня вдається до рефлексивних практик та шляхом «німого Intermezzo» (термін наш - О. П.) очищується від скверни, раціоналізує ступінь провини та досліджує власні життєві ресурси. У такий спосіб «несвідоме примушує людину усвідомити себе» [Юнг 2003 : 320]: «Відтоді Даруся втратила голос. <..> Покірно несла свій хрест усе життя, очищала душу в стражданні: і тілесному, i душевному. Але біль фізичний вона намагалася долати (можливо, для того, аби він не міг заглушити страждання душі): закопувала себе в землю (метафора вмирання / переродження - курсив - наш: О. П.), заходила у воду (метафора очищення / переродження), лікувалася травами (метафора очищення/ набування енергією з природних джерел)» [Цит. за: Підгорна 2017]. Моделлю архетипу Самість, безперечно, є певною мірою замкнений простір родини, той первинний i максимально доступний осередок соціалізації, у якому дитина, 3-поміж інших вражень, засвоює вихідний травматичний потенціал. Фізичний недолік (як результат конфлікту між змістом травми, його усвідомленням та способом актуального психологічного захисту, у тому числі - О. П.) може 
сприяти формуванню негармонійної «Я-концепції» у формі соціальнопсихологічної дезадаптації, а саме збіднілості соціальних контактів («Лище одна людина - Іван Цвичок - «чудний та дурнуватий, ... чоловік-зайда» змогла знайти илях до Дарусиного серия, викликати в неї знову довіру до людей» [Матіос 2005 : 13]) внаслідок внутрішньоособистісних конфліктів: «Ці двоє, відштовхнутих громадою, бо були не такі, як усі, змогли порозумітися» [Матіос 2005 : 13]. Так оприявнюється архетип Персона, який згодом еволюціонує до найвищого рівня колективного несвідомого «Бог»; формалізується через злиття з Анімусом (у Дарусі) та Анімою (у Івана).

Утворення символічної антиномії «слово дочки за умовну винагороду страта батьків», що й доводить психогенне (невротичне) походження комунікативної слабкості Дарусі, постійно провокована іншими ретравматизація: «стоїть у холодній купелі осені $i$ бореться із цзвяхами, забитими в голову чиїмось важким, безсердечним молотом» [Косинська 2009 : 27], «прощення (спокутування вини / гріха перед значимим дорослим) - символічний дозвіл на вербалізацію своїх переживань»: «... мова ӥй вертала у рот лиш тоді, як вона провідувала тата» (Приходячи на могилу до матері, Шарль промовляє ключові фрази: «Яке воно, пекло? Воно таке ж бридке, яким я його собі уявляю? Там так жахливо, як $і$ те, щуо ти примусила мене пережити?» [Quignard P. 1986 : 264]. Ці слова, насичені болем, відбивають головний внутрішній конфлікт протагоніста, водночас прив'заного до матері та відкинутого нею, а тому він прагне компенсувати нестачу спілкування з нею шляхом повернення фізично та у спогадах у родове гніздо у Вюртемберзі [Мацюк 2015]) безперечно, вказують на іiі здатність переробити внутрішній конфлікт за допомогою архетипів Вічної Дитини, Старого Мудреця, Діви та Духу.

Відстоюючи сферу абсолютних цінностей, Марія Матіос засвідчує руйнацію людини та дійсності («Tеперішні часи - не для життя, не для веселості, хіба лиш для думання та смерті»), активізуючи трагічне усвідомлення індивідом своєї долі в рамках філософської системи 
екзистенціалізму: відчуженість людини від суспільства, ïi «закиненість у ворожий світ», страх, самотність, неспокій, жах, відчай, внутрішній біль, проблема вибору [Косинська 2009 : 33]. Оскільки людина приречена бути вільною, але соціальний континуум та обов'язок заважають ій, вона обирає довільний, регламентований та дозволений внутрішньо, спосіб досягнення бажаної свободи.

Отже, «внутрішня еміграція» Дарусі та зовнішня маргіналізація під впливом товариства дозволяють їй досягти, пережити ідеально та фізично відчуття свободи, бути собою, у тому числі, і стати чужою для суспільства. У такий спосіб відбувається ініціація Самості героїні та реалізується архетип Індивідуації (з точки зору загалу - хибний, читай - дивний).

Висновки 3 даного дослідження і перспективи подальших розвідок у даному напрямку. Нам вдалося проаналізувати архетипну складову буковинського наративу Марії Матіос, досліджуючи засобами юнгіанської аналітики поведінкові стратегії героїні «трагедії, адекватної історії» - Дарини Ілащук. Текстуально підтверджено вияв архетипів Персона, Тінь, Аніма, Анімус, Самість, Індивідуація.

Також визначено архетипний базис ауторефлексії Дарусі (він збігається 3 класичною інтерпретацією К. Г. Юнга - О. П.): «<..> особливості несвідомого стану надто сильно контрастують із тим, щзо відбувається з комплексами у свідомості. Тут вони підлягають корекції: вони втрачають свій міфологічний покрив $i$, будучи задіяними в адаптаційному процесі, щзо протікає у свідомості, переживають персоналізацію та рацуіоналізацію, доки, нарешті, не стає можливим їх різнобічне обговорення» [Юнг 2002 : 35].

Метою подальших розвідок може бути дослідження циклічного коливання родинної історії на мікрорівні та заданість подій національної історії - на макрорівні як виявів архетипу Самість. 


\section{БІБЛІОГРАФІЯ}

Бідюк 2009 - Бідюк О.В. Психоаналіз драми Лесі Українки «На руїнах» / О. В. Бідюк // Науковий вісник Волинського національного університету імені Лесі Українки. - 2009. - № 23. - С. 3-7.

Вертипорох 2013 - Вертипорох О. Психоаналітична інтерпретація : методика i практика (на матеріалі оповідання Володимира Даниленка «Солом'яний пан») / О. Вертипорох // Вісник Черкаського університету. 2013. - № 5 (258). - C. 106-113.

Густодымова 2013 - Густодымова В. С. Феномен психологической зависимости как проблема личностного роста : юнгианский подход / В. С. Густодымова // Психологія в Україні та за кордоном. - Чернігів, 8-9 листопада 2013 р. - С. 14-19.

Косинська 2009 - Косинська Н. Божевілля як втеча від гендерної ролі в романі М. Матіос «Солодка Даруся» / Н. Косинська // Перша спроба. Студентська наукова творчість : Збірник матеріалів. - ЖДУ імені I. Франка. 2009. - T. 2. - C. 20-35.

Кузнецов 2014 - Кузнецов Ю. Психоаналіз як метод дослідження літератури (теоретичний аспект) / Ю. Кузнецов // Психологія і суспільство. 2014. - № 4. - C. 104-112.

Маланій 2014 - Маланій Н. І. Архетипні образи вогню та землі у романах I. Багряного «Людина біжить над прірвою» та Е. М. Ремарка «Час жити і час помирати» / Н. І. Маланій // Літератури світу : поетика, ментальність і духовність. - 2014. - Вип. 4. - С. 72-81.

Матіос 2005 - Матіос М. Солодка Даруся / М. Матіос. - Львів : ЛА «Піраміда», 2005. - 176 с.

Мацюк 2015 - Мацюк А. А. Архетип Медеи в философско-литературной концепции Паскаля Киньяра [Електронний ресурс]. Режим доступу : https:// periodicals. karazin. ua / philology/article/download/8273/7779/ 
Нестелєєв 2016 - Нестелєєв М. А. Автодеструктивний вимір архетипу самість у «Вершниках» Ю. Яновського / М. А. Нестелєєв // Літератури світу : поетика, ментальність і духовність. - 2017. - Вип. 7. - С. 154-161.

Підгорна 2017 - Підгорна О. М. Концепти фройдівської аналітики у прозописі Mapiï Матіос [Електронний ресурc] URL: http://textinternext.in.ua/pdf/n022017/oksana pidgorna 02_2017.pdf

Юнг 2002 - Юнг К. Г. О природе психе. Сборник. Пер. с англ. / К. Г. Юнг - Москва : «Рефлбук», Київ : «Ваклер», 2002. - 414 с.

Юнг 2003 - Юнг К. Г. Психология. Dementia praecox. Пер. Т. Э. Гусакова / К. Г. Юнг. - Мн. : ООО «Харвест», 2003. - 400 с.

Юнг 1998 - Юнг К. Г. Психологические аспекты архетипа матери / К. Г. Юнг // Бог и бессознательное. - Москва : Олимп, 1998. - 447 с.

Quignard 1986 - Quignard P. Le salon du Wurtemberg/ P. Quignard. - Paris : Gallimard, 1986. -432 p. 